\title{
Psychological Abuse in the Elderly During Exchanging News of COVID-19
}

\author{
Mohammad Karimian ${ }^{1}$, Feizollah Mansouri ${ }^{2}$, Gholamreza Gheiasi ${ }^{3}$, Laleh Solaimanizadeh ${ }^{4}$, \\ Masoomeh Otaghi ${ }^{5}$, Ebrahim Salimi ${ }^{5}$, Asma Tarjoman ${ }^{6,7,{ }^{*}}$ and Milad Borji ${ }^{8}$ \\ ${ }^{1}$ Ilam University of Medical Science, Ilam, Iran \\ ${ }^{2}$ Infectious Diseases Department, School of Medicine, Kermanshah University of Medical Sciences, Kermanshah, Iran \\ ${ }^{3}$ Islamic Education School of Medicine, Ilam University of Medical Science, Ilam, Iran \\ ${ }^{4}$ Department of Nursing, Faculty of Nursing and Midwifery, Bam University of Medical Science, Bam, Iran \\ ${ }^{5}$ Department of Nursing, Faculty of Nursing and Midwifery, Ilam University of Medical Science, Ilam, Iran \\ ${ }^{6}$ Student Research Committee, Ilam University of Medical Sciences, Ilam, Iran \\ ${ }^{7}$ Zoonotic Disease Research Center, Ilam University of Medical Sciences, Ilam, Iran \\ ${ }^{8}$ School of Allied Medical Sciences, Ilam University of Medical sciences, Ilam, Iran \\ "Corresponding author: Student Research Committee, Ilam University of Medical Sciences, Ilam, Iran. Tel: +98-183404704, Fax: +98-8433338228, Email: \\ asmatarjoman@yahoo.com
}

Received 2020 April 20; Accepted 2020 April 25.

Keywords: COVID-19, Aged, Abuse

\section{Dear Editor,}

Abuse is one of the instances of deprivation of human rights that occurs in various forms, such as psychological abuse, physical abuse, deprivation of authority, neglect, and rejection. Elderly abuse has many different forms, one of which is psychological abuse. This type of abuse is said to inflict pain on the elderly by depriving them of their choice, imposing personal opinions, and saying the words that hurt them $(1,2)$. Previous studies have reported a significant prevalence of abuse in the elderly, including 63.3\% in a study by Nassiri et al. (2) in Iran and $15.7 \%$ in a metaanalysis study in 28 countries by Yon et al. Therefore, it requires attention in this age group (3).

In the late months of 2019, an infectious disease called COVID-19 emerged in China. By 2020, it spread in the world like a pandemic disease, causing many problems for many countries. COVID-19 affects all age groups, but its mortality rate is higher among the elderly (4-6).

Unfortunately, people say: "Don't worry! The disease just kills the elderly" when they talk about COVID-19 prognosis in friendly informal gatherings or mass media. These folk conversations are examples of psychological abuse in the elderly. We must take interventions to prevent death due to COVID-19 in elderly people, too. More attention needs to be paid to the physical and psychological health of the elderly and promote their mental health and life expectancy. Elderly people need help in coping with the stress caused by COVID-19. Also, it is necessary to encourage the elderly to stay at home to prevent getting infected by the virus.

\section{Acknowledgments}

I would like to acknowledge the Ilam University of Medical Sciences.

\section{Footnotes}

Authors' Contribution: All authors have Contribution at all stages of the article, such as study concept and design, study supervision, drafting of the manuscript, and critical revision of the manuscript for valuable intellectual content. The final manuscript was approved by all authors. Conflict of Interests: There is no conflict of interest in this manuscript.

Funding/Support: There is no funding or support.

\section{References}

1. Heravi M, Anousheh M, Foroughan M, Sheikhi M, Hadjizadeh E. The meaning of domestic elderly abuse concept. Daneshvar. 2010;17(85):39-50. 
2. Nassiri H, Heravi Karimooi M, Jouybari L, Sanagoo A, Chehrehgosha M. The prevalence of elder abuse in Gorgan and Aq-Qala cities, Iran in 2013. Iran J Age. 2016;10(4):162-73.

3. Yon Y, Mikton CR, Gassoumis ZD, Wilber KH. Elder abuse prevalence in community settings: A systematic review and meta-analysis. Lancet Glob Health. 2017;5(2):e147-56. doi: 10.1016/S2214-109X(17)30006-2. [PubMed: 28104184].

4. Jiang F, Deng L, Zhang L, Cai Y, Cheung CW, Xia Z. Review of the clinical characteristics of coronavirus disease 2019 (COVID-19). J Gen Intern Med. 2020;35(5):1545-9. doi: 10.1007/s11606-020-05762-w. [PubMed: 32133578]. [PubMed Central: PMC7210321].
5. Yao TT, Qian JD, Zhu WY, Wang Y, Wang GQ. A systematic review of lopinavir therapy for SARS coronavirus and MERS coronavirus-A possible reference for coronavirus disease-19 treatment option. J Med Virol. 2020. doi: 10.1002/jmv.25729. [PubMed: 32104907]. [PubMed Central: PMC7217143].

6. Yang J, Zheng Y, Gou X, Pu K, Chen Z, Guo Q, et al. Prevalence of comorbidities and its effects in patients infected with SARS-CoV-2 A systematic review and meta-analysis. Int J Infect Dis. 2020;94:91-5. doi: 10.1016/j.ijid.2020.03.017. [PubMed: 32173574]. [PubMed Central: PMC7194638]. 